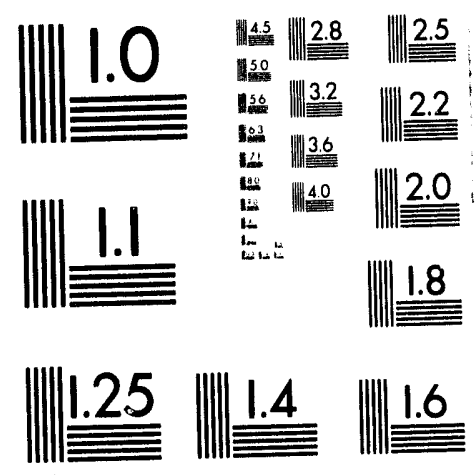




\section{Development of an Advanced, Continuous Mild Gasification Process for the Production of Co-Products}

\section{Quarterly Report}

April 1 - June 30, 1993

Glenn W. O'Neal

Work Performed Under Contract No.: DE-AC21-87MC24116

For

U.S. Department of Energy

Office of Fossil Energy

Morgantown Energy Technology Center

Morgantown, West Virginia

By

Coal Technology Corporation

Bristol, Virginia 


\section{DISCLAIMER}

This report was prepared as an account of work sponsored by an agency of the United States Government. Neither the United States Government nor any agency thereof, nor any of their employees, makes any warranty, express or implied, or assumes any legal liability or responsibility for the accuracy, completeness, or usefulness of any information, apparatus, product, or process disclosed, or represents that its use would not infringe privately owned rights. Reference herein to any specific commercial product, process, or service by trade name, trademark, manufacturer, or otherwise does not necessarily constitute or imply its endorsement, recommendation, or favoring by the United States Government or any agency thereof. The views and opinions of authors expressed herein do not necessarily state or reflect those of the United States Government or any agency thereof.

This report has been reproduced directly from the best available copy.

Available to DOE and DOE contractors from the Office of Scientific and Technical Information, P.O. Box 62, Oak Ridge, TN 37831; prices available at (615) 576-8401.

Available to the public from the National Technical Information Service, U.S. Department of Commerce, 5285 Port Royal Rd., Springfield, VA 22161; phone orders accepted at (703) 487-4650. 


\section{EXECUTIVE SUMMARY}

Seven briquette tests were made to show the effects of different volatile matter contents of chars on coke quality. Higher char volatiles in the range of $7.52 \%$ to $14.14 \%$ produced better quality coke. This correlation was determined for a low volatile coal, Pocahontas \#3, and a mid volatiles coal, Sewell Lady H.

Fifteen CMGU test runs were made using low volatile coal, Pocahontas \#3, and a mid volatile coal, Sewell Lady H. The 1000 pounds/hour design coal feed rate was exceeded at 1183 pounds/hour. Improvements to the vapor handling system were made including installation of a packed column demister and a tar trap condenser. Elimination of smoke emissions from the flare is in progress. 


\section{EXECUTIVE SUMMARY}

PAGE

INTRODUCTION

TASK 1. LITERATURE SURVEYS AND MARKET ASSESSMENT 3

$\begin{array}{ll}\text { Objective } & 3\end{array}$

Summary 3

TASK 2. BENCH-SCALE MILD GASIFICATION STUDY 3

$\begin{array}{ll}\text { Objective } & 3\end{array}$

Summary $\quad 3$

TASK 3. BENCH-SCALE CHAR UPGRADING STUDY 3

TASK 4. 1000 LB./HR. MILD GASIFICATION PDU 4 


\section{INTRODUCTION}

Petroleum currently accounts for over $42 \%$ of the total energy consumption in the United States; over $40 \%$ of the petroleum consumed in the United States is imported from foreign countries. The remaining oil reserve available in the United States is less than $6 \%$ of proven recoverable fossil energy reserves while over $90 \%$ of the proven recoverable reserves are coal (1)*. Total coal resources in the United States are estimated to be more than 3.9 trillion tons (2). Just the demonstrated reserves, that is, the deposits that are proven and can be economically mined using today's technologies and mining techniques amount to 488 billion tons. At an annual production rate of 900 mil.:ion tons per year, the demonstrated reserves alone will last more than 500 years. In view of the very abundant coal reserves and limited petroleum reserves, it would seem prudent to make good use of coal in our evermore difficult pursuit of energy independence.

Devising a continuous reactor system that can deliver a good quality co-products which require only minimal upgrading before being marketed is a major challenge. At present, mild gasification reactor configurations tend to fall into two broad categories: circulating or fluidized bed types characterized by high heating rates (up to $10,000^{\circ} \mathrm{C}$ per second, or fixed or moving bed types characterized by slow (on the order of 0.2 to $0.5^{\circ} \mathrm{C}$ per second) heating rates. Circulating or fluidized-bed types produce high liquid yields at the expense of quality. Fixed or moving-bed types produce better quality liquids but in lesser quantities. An optimum reactor is envisioned as one which avoids the secondary reactions associated with slow heating rates and the quality problems associated with high heating rates. Importantly, an optimum reactor would be capable of processing highly caking coals. The reactor concept under investigation in this effort is an advanced derivative of a reactor once used in prior commercial practice which approaches the characteristics of an optimum reactor.

It is important that a mild gasification reactor interface easily with the subsequent product upgrading steps in which the market value of the products is enhanced. Upgrading and marketing of the char are critical to the overall economics of a mild gasification plant because char is the major product (65 to $75 \%$ of the coal feedstock). In the past, the char product was sold as a "smokeless" fuel, but in today's competitive markets the best price for char as a fuel for steam generation would be that of the parent coal. Substantially higher prices could be obtained for char upgraded into products such as metallurgical coke, graphite, carbon electrode feedstock or a slurry fuel

*Numbers in parentheses indicate the reference listed at the end of this report. 
replacement for No. 6 fuel oil. In this effort, upgrading techniques are being developed to address these premium markets. Liquid products can similarly be upgraded to high market value products such as high-density fuel, chemicals, binders for form coke, and also gasoline and diesel blending stocks. About half of the non-condensible fuel gases produced by the gasification process will be required to operate the process; the unused portion could be upgraded into value-added products or used as fuel either internally or in "across the fence" sales.

The primary objective of this project is to develop an advanced continuous mild gasification process and product upgrading processes which will be capable of eventual commercialization. The program consists of four tasks. Task 1 is a literature survey of mild gasification processes and product upgrading methods and also a market assessment of markets for mild gasification products. Based on the literature survey, a mild gasification process and char upgrading method will be identified for further development. Task 2 is a bench-scale investigation of mild gasification to generate design data for a larger scale reactor. Task 3 is a bench-scale study of char upgrading to value adcied products. Task 4 is being implemented by building and operating a 1000-pound per hour demonstration facility. Task 4 also includes a technical and economic evaluation based on the performance of the mild gasification demonstration facility. 


\section{TASK 1. LITERATURE SURVEYS AND MARKET ASSESSMENT}

\section{Oblective}

The objectives of this Task are: (1) to identify the most suitable continuous mild gasification reactor system for conducting bench-scale mild gasification studies; (2) to identify the most feasible chemical or physical methods to upgrade the char, condensibles and gas produced from mild gasification into high profit end products; and (3) to assess the potential markets for the upgraded products from this process.

\section{Summary}

This task was completed and the Topical Report was submitted and approved by the DOE in January 1988 (3).

\section{TASK 2. BENCH-SCALE MILD GASIFICATION STUDY}

\section{Objective}

The objective of Task 2 is to study mild gasification in bench-scale reactor(s) to obtain the necessary data for proper design of the one ton/hour mild gasification screw reactor in Task 4.

\section{Summary}

After much consideration, it was concluded that it would not be necessary or desirable to build a bench-scale reactor. Instead, data and experience from Dr. David Camp's single screw reactor at Lawrence Livermore National Laboratory provided much useful information for the design of the reactor for this project. In addition, the information available from the literature on the eight years of operation of the Hayes process at Moundsville, West Virginia and the earlier Lauck's screw reactor supplied valuable process design data.

\section{TASK 3. BENCH-SCALE CHAR UPGRADING STUDY}

During the second quarter of 1993 seven coke briquette tests were made. Five tests were to evaluate how the volatile matter in char changes the coke quality and two to test how Sewell seam Lady $\mathrm{H}$ Mine coal worked as a binder coal. 
Three tests were made using Pocahontas \#3 coal to show how varying the volatile matter changed the coke product. Pocahontas \#3 coal is low volatile at about $16.70 \%$. All variables were held constant except the volatile matter in the char. The resulting data is below:

\begin{tabular}{|c|c|c|c|c|}
\hline Test & Volatile Matter & Crush Strength & CRI & CSR \\
\hline 167 & 14.14 & Plus 1000 & 34.4 & 54.3 \\
\hline 166 & 10.42 & Plus 1000 & 32.5 & 48.2 \\
\hline 165 & 7.52 & 430 & 43.0 & 7.3 \\
\hline
\end{tabular}

The coke made from char with 14.14 and 10.42 volatile matter is approximately equal and are both superior to the char with 7.52 volatile matter.

Test runs were made with char made from a middle volatile coal to support the data from the Pocahontas char. Coal from the Sewell seam, Lady H Mine, with volatile matter of $26.0 \%$ was chosen. The resulting data is below:

\begin{tabular}{|c|c|c|c|c|}
\hline Test & Volatile Matter & Crush Strength & CRI & CSR \\
\hline 170 & 12.80 & Plus 1000 & 31.3 & 63.2 \\
\hline 171 & 11.88 & Plus 1000 & 34.5 & 55.2 \\
\hline
\end{tabular}

Higher volatile matter in the char does make better coke as long as the char has gone through the plastic stage of the feed coal sufficiently to eliminate swelling in the char. The higher volatile char is easier to wet with binder. This data indicates that coke from char of about $12 \%$ or $13 \%$ would give the best quality.

The tests using Lady $\mathrm{H}$ coal as binder coal produced good but not the best coke with a CSR of 52.2 and 42.2. The coal has a FSI of 9 which is too high to produce the best coke. Lower swelling binder coal produces coke with less swelling which allows the use of higher percentages of binder coal. Higher percentages of binder coal produces coke with better CRI and CSR qualities as well as better economics.

\section{TASK 4. 1000 LB/HR CONTINUOUS MILD GASIFICATION UNIT (CMGU)}

A total of 15 CMGU test runs were made during the second quarter of 1993. Low volatile and mid volatile coals were processed to provide chars for converting to formed coke. Operating conditions were varied to produce chars in the range of $8.0 \%$ to $12 \%$ volatiles from the two types of coals. 
The CMGU designed coal feed rate of 1000 pounds per hour average was exceeded during test run 11-93 at 1183 pound per hour and several other runs were near the 1000 pound per hour rate.

Determination of the minimum heat input to the CMGU per pound of feed coal shows that higher feed rates increase the heat efficiency by $53 \%$.

Efforts to improve the condenser system have been ongoing to minimize liquid product loss and emissions to the atmosphere. Improved operation of the original condensers eliminated water in the coal liquids. Addition of a packed column demister in the flare line decreased the amount of oil going to the flare. An aerosol suspension still causes a small amount of oil going to the flare which results in smoke generation.

An experimental bubble type water scrubber successfully broke this aerosol and the off gas from the scrubber was free of oil. A larger scrubber will be fabricated to evaluate the design.

An experimental condenser was fabricated to provide separation of tar and particulates prior to cooling the off gas stream. The condenser efficiently separates tar and particulates, but the condensation of coal liquids is less than desired. The tar resembles pitch and should be a good binder for formed coke production. Also removing the tar and particulates greatly decreases plugging of condensing systems for the coal liquids.

There were no major maintenance problems during the quarter. The jet burners heating the screw shafts have eliminated over loading the pyrolyzer hydraulic drive system. The 310 stainless steel screw shafts show no signs of deterioration.

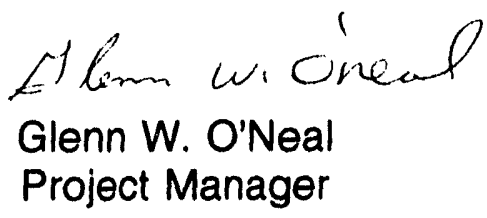



Gasification Process for the Production of Co-Products

\author{
Quarterly Report \\ April 1 - June 30, 1993
}

Glenn W. O’Neal

Work Performed Under Contract No.: DE-AC21-87MC24116

\author{
For \\ U.S. Department of Energy \\ Office of Fossil Energy \\ Morgantown Energy Technology Center \\ P.O. Box 880 \\ Morgantown, West Virginia 26507-0880
}

By

Coal Technology Corporation

103 Thomas Road

Bristol, Virginia 24201 


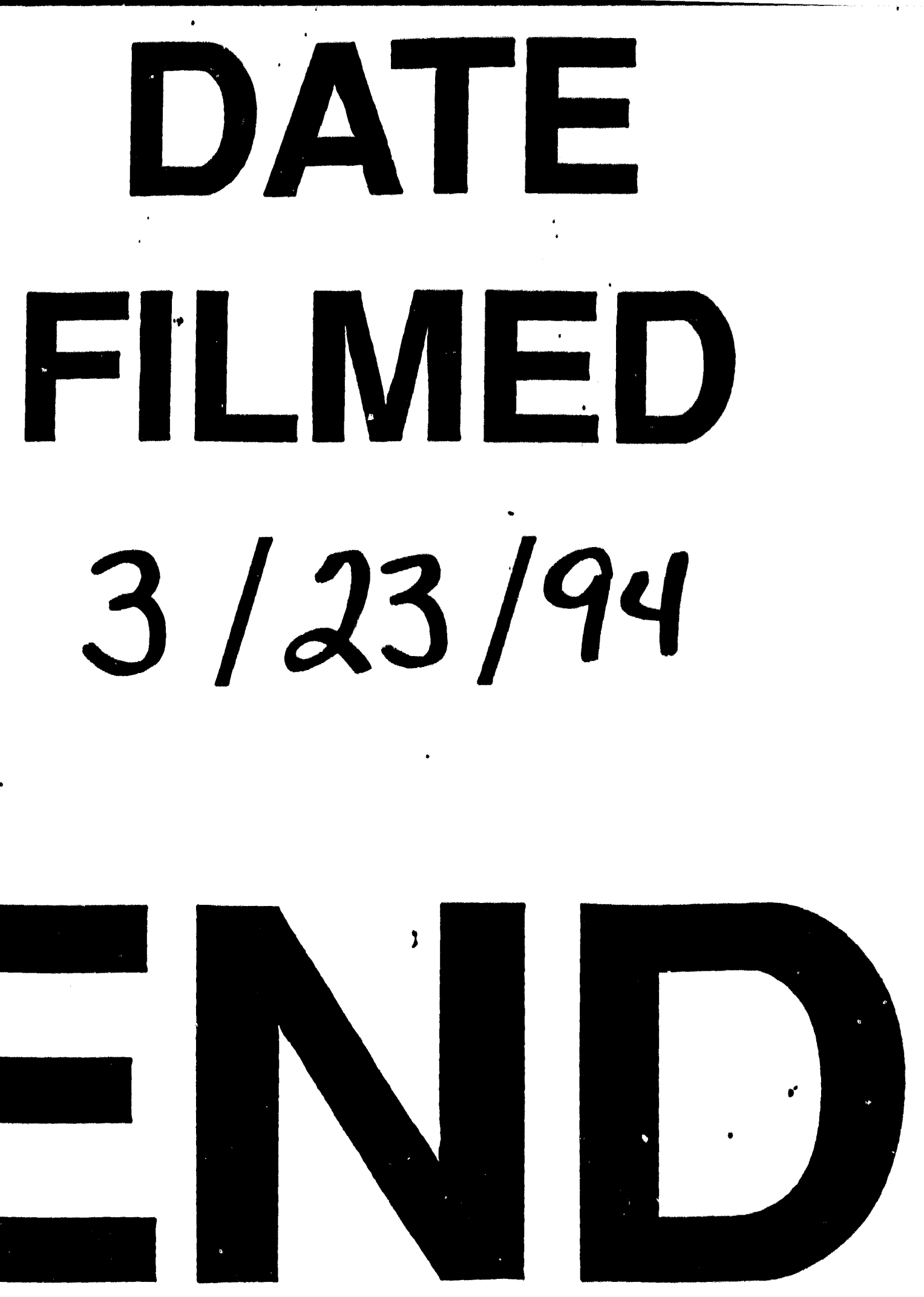

